\title{
Çocuklarda Henoch-Schönlein Purpurası: 53 olgunun retrospektif değerlendirilmesi
}

\section{Henoch-Schönlein Purpura in Children: Retrospective evaluation of 53 cases}

\author{
Samet Özer ${ }^{1}$, Tuba Kasap ${ }^{2}$, Resul Y1lmaz ${ }^{1}$, Ergün Sönmezgöz ${ }^{1}$, Şeyma Ünüvar ${ }^{1}$
}

${ }^{1}$ Gaziosmanpaşa Üniversitesi Tıp Fakültesi Çocuk Sağlığı ve Hastalıkları AD Tokat/ Türkiye

${ }^{2}$ Kelkit Devlet Hastanesi c Çocuk Sağlığı ve Hastalıkları Kliniği Gümüşhane/ Türkiye

\section{Corresponding Author:}

Dr. Tuba Kasap

\section{Address:}

Kelkit Devlet Hastanesi c Çocuk Sağlığı ve Hastalıkları Kliniği Gümüşhane/ Türkiye

Telefon : $+90(456) 3171029$

Faks : +90(456) 3171572

Email:

tubaserdar06@hotmail.com

Başvuru Tarihi/Received :

26-08-2015

Kabul Tarihi/Accepted:

02-09-2015

\section{ÖZET}

Amaç: Henoch-Schönlein purpurası (HSP) çocukluk çağında en sık görülen vaskülit olup; başta deri, eklem, böbrek ve GíS olmak üzere birçok organı etkileyebilen sistemik bir hastalıktır. Bu çalışmanın amacı 2010-2015 yılları arasında kliniğimizde HSP tanısı ile izlenen hastaların klinik ve laboratuvar özelliklerinin değerlendirilmesidir.

Gereç ve Yöntem: Bu çalışmada Tokat Gaziosmanpaşa Üniversitesi Tıp Fakültesi Çocuk Sağlığı ve Hastalıkları Kliniği’nde 2010-2015 yılları arasında HSP tanısı alarak tedavi ve takibi yapılan 53 hastanın dosyaları geriye dönük olarak incelendi. Hastaların tanısı; 1990 Amerikan Romatoloji Birliği HSP tanı ölçütlerine göre en az iki ölçütün var olmasına dayanılarak konuldu. Tedavide nonsteroid antienflamatuvar ve/veya kortikosteroid kullanıldı.

Bulgular: Hastaların 28'i kız, 25'i erkekti. Hastaların yaş aralığı 3-17 yıl, yaş ortalaması 9,8 yıl idi. Klinik bulgulardan cilt döküntüsü hastaların tamamında mevcuttu. Artrit/artralji 24 (\%45.3), karın ağrısı 33 (\%62.3), baş ağrıs1 6 (\%11.3) hastada görüldü. Proteinüri $22(\% 41)$, hematüri $9(\% 17)$ ve gaitada gizli kan pozitifliği $20(\% 37.7)$ hastada tespit edildi. 25 hastada (\%47) böbrek tutulumu, 33 hastada (\%62.3) Gís tutulumu mevcuttu. GíS tutulumu olan 20 hastaya (\%37.7) steroid tedavisi verildi. 6 hasta (\%11) ağır böbrek bulguları olması nedeniyle ileri inceleme yapılmak üzere Çocuk Nefroloji Kliniği olan dış merkeze sevk edildi. 15 (\%28.3) hastada döküntülerin tamamen geçtikten sonra ilk 6 ay içinde tekrar ortaya çıktığı görüldü.

Sonuç: HSP cilt ve eklemler başta olmak üzere birçok organ ve sistemi tutabilen bir vaskülit olup, kısa dönemde prognozunun iyi olduğu ve hastaların çoğunluğunun sekelsiz iyileşebildiği görülmüştür. Bununla beraber erken ve geç dönemde gelişebilecek özellikle Gís ve böbrek tutulumu gibi komplikasyonlar açısından yakın takip edilmelidir.

\section{Anahtar Kelimeler: Henoch-Schönlein purpurası, çocuk}




\section{Giriş}

Henoch-Schönlein purpuras1 (HSP); etyolojisi tam olarak bilinmeyen, başta cilt olmak üzere eklemler, gastrointestinal sistem (GİS), böbrekler ile daha ender olarak diğer organların etkilendiği, küçük damarları tutan bir lökositoklastik vaskülittir [1]. Çocukluk çağında görülen trombositopenik olmayan purpuranın en sik sebebidir. Genel olarak 5-15 yaş grubunda görüldüğü için bir çocukluk çağ 1 hastalığ1 olarak değerlendirilebilir. Hastalığın 17 yaş altında yıllık görülme insidansının 1320/100.000 arasinda olduğu tahmin edilmektedir [2]. HSP tanısı için 1990 y1lında Amerikan Romatoloji Birliği tarafindan oluşturulmuş olan tanı kriterleri yaygın olarak kullanılmaktadır [3]. Bu kriterler;

1. Trombositopeni olmaksızın görülen, yüzeyden hafifçe kabarık, dokunmakla hissedilebilen hemorajik cilt lezyonu (palpabl purpura),

2. İlk belirtilerin ortaya çıtı $\breve{g}_{1}$ anda hastanın yaşının 20'nin altında olması,

3. Yemeklerle şiddetlenen yaygın karın ağrısı veya kanlı ishal gibi barsak iskemisi bulgularının bulunması,

4. Arteriol ve venül duvarlarında granülosit varlığını gösteren histolojik bulguların saptanmasıdır.

$\mathrm{Bu} 4$ kriterden en az 2'sinin olmasiyla hastaya HSP tanısı konabilir.

Patogenezi tam olarak bilinmemekle birlikte HSP'de immünoglobülin A (IgA)'nın çok önemli rol oynadığı düşünülmektedir. Artan yapım veya renal klirensin azalmasına bağlı olarak serum IgA düzeyi genellikle artmıştır. Tutulan organların küçük damarlarında IgA içeren immün kompleks birikimi ve inflamasyon görülmektedir. Patognomonik bulgu lökositoklasis yani parçalanmış lökositlerin varlığıdır [4].

Hastaların 2/3'ünde geçirilmiş bir üst solunum yolu enfeksiyonu (ÜSYE) hikayesi olması ve hastalı̆̆ı solunum yolu enfeksiyonlarının yoğun olarak görüldüğü kış ve ilkbahar aylarında daha sık görülmesi; rastlantısal olabileceği gibi HSP'nin enfeksiyon hastalıkları ile ilişkisi olduğunu da düşündürmektedir. $\mathrm{Bu}$ noktada üzerinde en fazla durulan mikroorganizma streptokoklardır [5]. Bunun dışında birçok viral ve bakteriyel enfeksiyon sonrasında geliştiği de bildirilmiştir $[1,6]$.

Klinik olarak HSP'li hemen tüm hastalarda kalça ve alt ekstremite cildinde trombositopenik olmayan palpabl purpura görülür. Daha az sıklıkta özellikle alt ekstremite eklemlerinde artrit/artralji ve ödem, GíS tutulumuna bağlı karın ağrısı, melena, hematokezya, böbrek tutulumuna bağlı hematüri ve proteinüri görülebilir. Çoğunlukla iyi seyirli bir hastalı olan HSP nadir de olsa özellikle böbrek tutulumu ya da GIS tutulumuna bağlı olarak morbidite ve mortaliteye neden olabilmektedir $[1,5,6]$.

HSP'nin tedavisi esas olarak destekleyici özelliktedir. Sadece cilt ve eklem tutulumu olan HSP'li olguların çoğunda yatak istirahati, hidrasyon ve analjeziklerle sekelsiz düzelme görülürken GíS, böbrek ve diğer organ tutulumlarinda steroidler ve immunsupresifler kullanılmaktadır [1,4,6,7].

HSP genellikle iyi seyirli ve sekel bırakmayan bir hastalıktır ve ortalama 4-6 hafta kadar sürer ancak relaps görülebileceği bilinmektedir.

$\mathrm{Bu}$ çalışmanın amacı; 2010-2015 y1lları arasında son 5 yıl içinde Tokat Gaziosmanpaşa Üniversitesi Tip Fakültesi Çocuk Sağlığı ve Hastalıkları Kliniği'nde HSP tanısı ile izlenen hastaların klinik ve laboratuvar özelliklerinin değerlendirilmesidir.

\section{Materyal ve Metod}

$\mathrm{Bu}$ çalışmada Tokat Gaziosmanpaşa Üniversitesi Tıp Fakültesi Çocuk Sağlığ ve Hastalıkları Kliniği'nde 2010-2015 yılları arasinda HSP tanisi alarak tedavi ve takipleri yapılan 53 hastanın dosyaları geriye dönük olarak incelendi. Hastaların tanıs1; 1990 Amerikan Romatoloji Birliği HSP tanı kriterlerine göre en az iki kriterin var olmasına dayanılarak konuldu [3].

Hastalarda artralji ve/veya artrit olmas1 eklem tutulumu, karın ağrısı ve/veya gaitada gizli kan (GGK), melena veya hematokezya olması GIS tutulumu olarak kabul edildi. Renal 
tutulum hastalığın seyri sirasında ortaya çıkabilecek bulgulara göre tanımlandı. Mikroskopik hematüri, idrar mikroskopik incelemesinde $40^{\prime} 11 \mathrm{k}$ büyütmede alanda 5 'ten fazla eritrosit görülmesi olarak tanımlandı. Proteinüri araştırması için sabah ilk idrarda bakılan protein/kreatinin oranı 0.2 üzerinde olan hastalardan 24 saatlik idrar toplandi. Protein atılımı $4 \mathrm{mg} / \mathrm{m}^{2} / \mathrm{st}$ üzerinde olanlar proteinüri olarak adlandırıldı. Nefrotik sendrom $\left(>40 \mathrm{mg} / \mathrm{m}^{2} / \mathrm{saat}\right)$ ve/veya nefritik sendrom durumunda ise ağır böbrek tutulumu olduğu kabul edildi. Ağır böbrek tutulumu olan hastalar ileri tetkik ve tedavi için Pediatrik Nefroloji Kliniği bulunan merkezlere sevk edildi.

Çalışmada hastaların tedavisinde izole cilt tutulumu olanlar medikal tedavi verilmeden istirahat önerilerek izleme alındı. Eklem tutulumu olanlara ağrıyı azaltmak icin nonsteroid antiinflamatuar ilaç -ibuprofenbaşlandı. Gastrointestinal tutulumu olanlara hidrasyon ve endike olduğu durumlarda steroid tedavisi prednizolon $-2 \mathrm{mg} / \mathrm{kg} /$ gün- verildi.

Çalışmaya dahil edilen hastalar incelenerek yaş, cinsiyet, başvuru şikayetleri, fizik muayene bulguları, yakın zamanda (son 3 hafta içinde) enfeksiyon geçirme öyküsü, başvuru mevsimi, tedavide kullanılan ilaçlar ve takipte izlenen komplikasyonlar kaydedildi. Laboratuvar bulgularından tam kan sayımı, biyokimya, eritrosit sedimantasyon hızı (ESH), C-reaktif protein (CRP), tam idrar tahlili, GGK sonuçları incelendi.

\section{Bulgular}

Çalışmaya toplam 53 hasta dahil edildi. Hastaların 28'i k1z, 25'i erkekti. Hastaların yaş aralığı 3-17, yaş ortalaması 9.8 idi. Hastaların 16'sında (\%30.2) üst solunum yolu enfeksiyonu (ÜSYE), 5'inde (\%9.4) idrar yolu enfeksiyonu (İYE), 9'unda (\%17) akut gastroenterit (AGE) geçirme öyküsü mevcutken 23 (\%43.4) hastada herhangi bir enfeksiyon öyküsü tespit edilmedi. Hastaların 15'i (\%28.3) sonbahar, 21'i (\%39.6) kış, 9'u (\%17) ilkbahar, 8'i (\%15) yaz aylarında başvurdu (Tablo 1). Klinik bulgulardan cilt döküntüsü hastaların tamamında mevcuttu. Artrit/artralji 24 (\%45.3), karın ağrıs1 33 (\%62.3), baş ağrıs1 6 (\%11.3) hastada görüldü.
25 hastada (\%47) böbrek tutulumu, 33 hastada (\%62.3) GİS tutulumu mevcuttu (Tablo 2). Proteinüri 22 (\%41), hematüri $9(\% 17)$ ve GGK pozitifliği $20(\% 37.7)$ hastada tespit edildi. Laboratuvar bulgularından lökositoz 19 hastada (\%35), trombositoz 11 hastada (\%20), anemi 12 hastada (\%22.6) saptand. Eritrosit sedimantasyon hizı 10 hastada (\%18), CRP 26 hastada (\%49) pozitif bulundu (Tablo 3). GIS tutulumu olan 20 hastaya (\%37.7) steroid tedavisi verildi. 6 hasta $(\% 11)$ ağır böbrek tutulumu olmasi nedeniyle ileri inceleme yapılmak üzere Çocuk Nefroloji Kliniği olan diş merkeze sevk edildi. 15 (\%28.3) hastada döküntülerin tamamen geçtikten sonra ilk 6 ay içinde tekrar ortaya çıktığı görüldü.

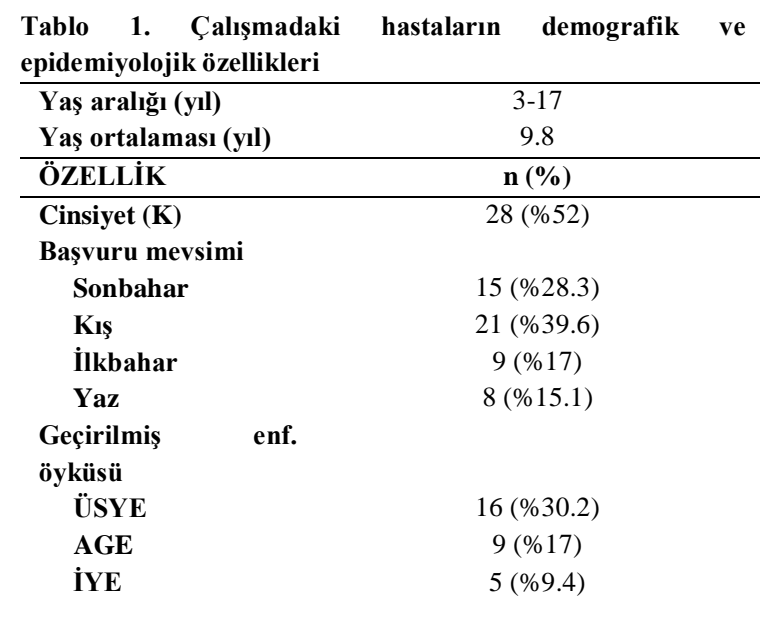

Tablo 2. Çalışmadaki hastaların organ-sistem tutulumları

\begin{tabular}{lcc}
\hline Klinik bulgu & $\mathbf{n}$ & $\%$ \\
\hline Cilt tutulumu & 53 & 100 \\
Eklem tutulumu & 24 & 45.3 \\
Böbrek tutulumu & 25 & 47 \\
GíS tutulumu & 33 & 62.3
\end{tabular}

Tablo 3. Çalışmadaki hastaların laboratuvar özellikleri

\begin{tabular}{lcc}
\hline Bulgu & n & \% \\
\hline Lökositoz & 19 & 35 \\
Anemi & 12 & 22.6 \\
Trombositoz & 11 & 20 \\
CRP pozitifliği & 26 & 49 \\
ESR pozitifliği & 10 & 18 \\
Proteinüri & 22 & 41 \\
Hematüri & 9 & 17 \\
GGK pozitifliği & 20 & 37.7 \\
\hline
\end{tabular}

\section{Tartışma}

Henoch-Schönlein purpuras1; etyolojisi tam olarak bilinmeyen, başta cilt olmak üzere eklemler, GİS, böbrekler ile daha ender olarak 
diğer organların etkilendiği, küçük damarları tutan bir lökositoklastik vaskülittir [1]. Genellikle 5-15 yaşları arasında, ortalama 5-6 yaş civarında ortaya cıktığı bildirilmektedir [7,8,9]. Çalışmamızdaki hastalar 3-17 yaşları arasında olup yaş ortalaması 9.8 idi. HSP'nin genellikle erkeklerde daha sık görüldügü bilinmekle beraber kızlarda daha yüksek oranda görüldüğünü bildiren bazı çalışmalar da mevcuttur $[9,10,11,12]$. Bizim çalışmamızda erkek ve kız cinsiyetleri arasında belirgin fark olmamakla beraber, kızlarda daha sik (\%52) görüldüğü bulundu. HSP'nin sonbahar ve k1ş aylarında ve bazı çalışmalarda ilkbahar aylarında daha sık görüldüğü bildirilmektedir $[13,14]$. Bu çalışmada da hastaların çoğunluğunun $\quad(\% 39.6) \quad$ kış $\quad$ aylarında başvurduğu bulundu. HSP'de yakın zamanda geçirilen enfeksiyonların hastalığ 1 tetikleyici olabileceği düşünülmektedir. Bu çalışmada da hastaların \%56.6'sında yakın zamanda geçirilmiş enfeksiyon öyküsü (en sık ÜSYE) olduğu bulundu.

HSP'de çoğunlukla kalça ve alt ekstremite gibi vücudun ağırlık taşıyan bölgelerinde yoğunlaşan purpurik döküntü (palpabl purpura) hastalık için karakteristik olup genellikle tanı koydurucudur. Literatürdeki çeşitli yayınlarda nontrombositopenik palpabl purpuranın olguların hepsinde görülen tek bulgu olduğu bildirilmiştir $[8,12,15]$. Bu çalışmada da tüm hastalarda cilt tutulumu olduğu görüldü.

HSP'de genellikle en sik rastlanan ikinci bulgu eklem tutulumu olup (\%50-80) sekelsiz iyileştiği bilinmektedir $[8,12,16]$. En s1k tutulan eklemler dizler ve ayak bilekleri gibi büyük eklemlerdir [17]. Bizim çalışmamızda ise eklem tutulumunun \%45.3 oranında görüldüğü ve siralamada gastrointestinal tutulumdan sonra geldiği bulundu. $\mathrm{Bu}$ hastalara bulguları düzelinceye kadar nonsteroidal antiinflamatuar ilaç tedavisi verildi, deformite bırakmadan iyileştiği görüldü.

Gís tutulumu genellikle iyi seyir gösterirken ağır tutulum erken dönemde mortalite ve morbiditenin en önemli sebebidir.
Klinik olarak karın ağrısı, bulantı, kusma ile kendini göstermekte, melena, hematokezya (nadir) ve daha çok GGK pozitifliği eşlik edebilmektedir. Kanama olduğunda steroid tedavisi verilmekte ağır vakalarda immünsüpresif ilaçlar, intravenöz immünoglobülin ve plazmaferez gibi diğer tedaviler kullanılmaktadır [18]. İnvajinasyon GİS tutulumunun en sik cerrahi komplikasyonudur. Literatürdeki çalışmalarda GiS tutulumu \%38-75 oranında bildirilmektedir $[19,20]$. Bizim çalışmamızda GİS tutulumu oranı \%62.3 olarak bulunmuş olup literatür ile uyumlu idi. \%37.7 oranında (tüm hastalar içinde) GGK pozitifliği saptand, melena veya hematokezya görülen hasta olmadı. GİS tutulumu olan 20 hastaya (\%37.7) steroid tedavisi verildi ve hepsinde tedavi sonras1 düzelme gözlendi. Cerrahi komplikasyon gelişen hasta olmadi.

Böbrek tutulumu HSP'nin uzun dönemde en önemli komplikasyonu ve nadir de olsa morbidite ve mortalite sebebidir [21]. Siklığı \%10-90 gibi geniş bir aralıkta bildirilmektedir [8,14,15,22,23]. HSP nefriti birkaç hafta sürebilen ve kendiliğinden düzelen izole mikroskobik hematüriden veya hafif proteinüriden hizlı ilerleyen glomerülonefrite kadar değişen bir yelpazede kendini gösterebilir ve \%1-4 oranında kronik böbrek yetmezliği ile sonuçlanabilir $[15,17,24]$. Genellikle hastalığın ilk dört haftasında ortaya çıtığı ve persistan purpura ve/veya ciddi GİS tutulumu olanlarda daha sik görüldüğü bildirilmektedir [9,25]. Prognozu belirleyen en önemli faktörün renal semptomların başlangıçtaki şiddeti olduğu belirtilmiştir. HSP gelişen tüm hastalarda başlangıçta idrar analizi, serum kreatinin seviyesi ve arteriyel kan basıncı değerlendirilmelidir. Hastalığın aktif olduğu dönemde en az ilk yedi gün, daha sonra da 1 ay boyunca haftada bir kez idrar analizi yapılmalıdır. Böbrek tutulumu geç dönemde de görülebileceğinden en az bir yil boyunca giderek azalan sıklıkta takip yapılmalıdır. Bizim çalışmamızda 25 hastada (\%47) böbrek tutulumu saptanmış olup takipleri sırasında bulguları düzelmeyen ve ağır tutulumu olan 6 
hasta ileri inceleme ve gerektiğinde steroid veya immünsüpresif ilaçlarla tedavi edilmek üzere Çocuk Nefroloji Kliniği olan merkeze sevk edilmiştir.

Sadece cilt ve eklem tutulumu olan HSP'li olguların çoğunda yatak istirahati, hidrasyon ve analjeziklerle sekelsiz düzelme görülürken GIS, böbrek ve diğer organ tutulumlarında steroidler ve immunsupresifler kullanılmaktadır. Ancak bu ilaçların prognoza etkisi ve kullanım endikasyonu açısından dünyada bir görüş birliği yoktur [16,26]. Bu nedenle literatürdeki çalışmalarda da steroid verilen vakaların oranları çok farklı1ık göstermektedir. Bizim çalışmamızdaki hastalarımızın büyük çoğunluğu yatak istirahati, hidrasyon ve nonsteroid antiinflamatuar ilaçlarla takip edilmiş, Gís tutulumu olan 20 hastaya (\%37.7) steroid verilmiştir ve bu hastalarda düzelme görülmüştür.

Sonuç olarak; HSP'nin cilt ve eklemler başta olmak üzere birçok organ ve sistemi tutabilen bir vaskülit olduğu, kısa dönemde prognozunun iyi olduğu ve hastaların çoğunluğunun sekelsiz iyileşebildiği görülmüştür. Bununla beraber erken ve geç dönemde gelişebilecek özellikle GİS ve böbrek tutulumu gibi komplikasyonlar açısından hastaların yakın takip edilmesi gerekmektedir.

\section{Kaynaklar}

1. Yang $\mathrm{YH}, \mathrm{Yu} \mathrm{HH}$, Chiang BL. The diagnosis and classification of Henoch-Schonlein purpura: an updated review. Autoimmun Rev 2014;13(4-5):355-8.

2. Yang $\mathrm{YH}$, Hung $\mathrm{CF}, \mathrm{Hsu} \mathrm{CR}$, Wang LC, Chuang $\mathrm{YH}, \mathrm{Lin} \mathrm{YT}$ et al. A nationwide survey on epidemiological characteristics of childhood Henoch-Schonlein purpura in Taiwan. Rheumatology (Oxford) 2005;44(5):618-22.

3. Mills JA, Michel BA, Bloch DA, Calabrese LH, Hunder GG, Arend WP et al. The American College of Rheumatology 1990 criteria for the classification of HenochSchonlein purpura. Arthritis Rheum 1990;33(8):1114-21.

4. Onat T. Henoch-Schönlein Vasküliti. Çocuk Sağlığı ve Hastalıkları cilt II. Eksen Yayınları 1996;987-9.

5. Al-Sheyyab M, El-Shanti H, Ajlouni S, Sawalha $\mathrm{D}$, Daoud A et al. The clinical spectrum of Henoch-Schonlein purpura in infants and young children. Eur $\mathrm{J}$ Pediatr 1995;154(12):969-72.
6. Kawasaki Y. The pathogenesis and treatment of pediatric Henoch-Schonlein purpura nephritis. Clin Exp Nephrol 2011;15(5):648-57.

7. Cassidy JT, Petty RE. Leukocytoclastic vasculitis. In: Cassidy JT, Petty RE, editors. Textbook of Pediatric Rheumatology. 5th ed. W.B. Saunders Co. Philadelphia 2005; 496-501.

8. Saulsbury FT. Henoch Schonlein purpura in children: report of 100 patients and review of the literature. Medicine 1999;78:395-409.

9. Gürgöze MK, Gündüzalp M. Cocuklarda HenochSchönlein Purpurası: 50 Olgunun Retrospektif Değerlendirilmesi. Firat Tip Dergisi 2010;15(1):27-30.

10. Tizard EJ. Henoch-Schonlein purpura. Arch Dis Child 1999;89:380-3.

11. Garcia-Porrua C, Calvino MC, Llorca J, Couselo JM, Gonzalez Gay MA. Henoch-Schonlein purpura in children and adults: clinical differences in a defined population. Semin Arthritis Rheum 2002;32:149-156.

12. Calvino MC, Llorca J, Garcia-Porrua C, Fernandez Iglesias JL. Henoch-Schonlein purpura in children from Northwestern Spain. Medicine (Baltimore) 2001;80:279-90.

13. Nuhoğlu Ç, Gedikoğlu H, Sönmez EO, Ozkozacı T, Ceran O. Henoch-Schönlein Purpurası olan çocuk olguların demografik özellikleri ve laboratuar bulgularının retrospektif analizi. Haydarpaşa Numune Eğitim ve Araştırma Hastanesi Tıp Dergisi 2009;49(2):125-9.

14. Cakır M. Henoch-Schonlein purpura in North-Eastern Turkey. Ann Trop Paediatr 2006;26(1):59-65.

15. Trapani S, Micheli A, Grisolia F, Resti M, Chiappini E, Falcini F. Henoch-Schonlein Purpura in Childhood: Epidemiological and Clinical Analysis of 150 Cases Over a 5year Period and Review of Literature. Semin Arthritis Rheum 2005;35:143-53.

16. Ece A, Yolbaş İ, Balık H, Kocamaz H, Yel S, Uluca Ü ve ark. Cocuklarda Henoch-Schönlein purpurası: 214 hastanın değerlendirilmesi. Journal of Clinical and Experimental Investigations 2012;3(1):91-5.

17. Dönmez O,Yildırım NS, Durmaz O. Henoch Schonlein Purpuralı 137 Olgunun 10 Yillı Retrospektif Değerlendirilmesi. Güncel Pediatri 2011;9:63-7.

18. Acar BÇ, Arıkan Y, Arıkan Fİ, Dallar Y. Çocukluk çağında henoch schönlein purpurası tanısı ile izlenen 168 olgunun sistem tutulumlarının değerlendirilmesi. Ege Tıp Dergisi 2010;49(1):7-12.

19. Bagga A, Kabra SK, Srivastava RN, Bhuyan UN. Henoch-Schönlein syndrome in Northern Indian children. Indian Pediatr 1991;28(10):1153-7.

20. Gow KW, Murphy JJ, Blair GK, Hailey J et al. Multiple entero-entero fistulae: an unusual complication of Henoch- Schönlein purpura. J Pediatr Surg 1996;31(7):809-11.
21. Davin JC, Coppo
R. HenochSchönlein purpura nephritis in children. Nat Rev Nephrol 2014;10(10):563-73.

22. Muslu A, Gök F, Dilber C, Dağdemir A, İşlek İ, Küçüködük S. Henoch Schönlein Vaskülitli olguların değerlendirilmesi. Ondokuz Mayıs Üniversitesi Tıp Dergisi 2001;18(4):277-82.

23. Ersen A, Aydınöz S, Karademir F, Süleymanoğlu S, Meral C, Özkaya H ve ark. Çocukluk Dönemi Henoch-Schönlein Purpurası: 42 Olgunun Retrospektif Analizi. Dirim Tıp Gazetesi 2009;84(2):35-41.

24. Chen JY, Mao JH. HenochSchönlein purpura nephritis in children: incidence, pathogenesis and management. World J Pediatr 2015;11(1):29-34.

25. Kaku Y, Nohara K, Honda S. Renal involment in Henoch-Schonlein purpura: A multivariate anlysis of prognostic factors. Kidney Int 1998;53:1755-59.

26. Kawasaki Y, Suziki J, Nozawa R, Suziki S, Suziki H. Efficacy of metilprednisolone and urokinase pulse therapy for severe Henoch-Schonlein nephritis. Pediatrics 2003;111:785-9. 